\title{
Bottlenecks in the migration routes of Amazonian manatees and the threat of hydroelectric dams
}

\author{
Eduardo Moraes ARRAUT ${ }^{1,2^{*}}$, José Luis ARRAUT³ ${ }^{3}$, Miriam MARMONTEL ${ }^{4}$, José Eduardo MANTOVANI ${ }^{5}$, \\ Evlyn Márcia Leão de Moraes $\mathrm{NOVO}^{2}$ \\ Oxford University, Zoology Department, Wildlife Conservation Research Unit, The Recanati-Kaplan Centre, Tubney House, Abingdon Road, Tubney, \\ Abingdon, OX13 5QL, UK (EMA) \\ 2 Instituto Nacional de Pesquisas Espaciais, Divisão de Sensoriamento Remoto, São José dos Campos, SP, Brasil (EMA) \\ ${ }^{3}$ Universidade de São Paulo, Instituto de Ciências Matemáticas e de Computação, São Carlos, SP, Brasil (JLA) \\ ${ }^{4}$ Instituto de Desenvolvimento Sustentável Mamirauá, Tefé, AM, Brasil (MM) \\ ${ }^{5}$ Instituto Nacional de Pesquisas Espaciais, Centro Regional de Natal, Natal, RN, Brasil (JEM) \\ *Corresponding author: eduardo.arraut@gmail.com ; eduardo.arraut@inpe.br
}

\begin{abstract}
In a particular region within western Amazonia, Amazonian manatees (Trichechus inunguis) live in a floodplain environment that becomes inhospitable for them during the annual low-water season. To flee from it, they undergo a dangerous migration to a refuge while water levels are dropping fast. Our aim was to better understand the role of depth variation in this migratory process. We analyzed the sole tracking data on wild manatees ( $\mathrm{n}=10$ males), 30 years of Landsat images, a 14-year hydrograph and a 3-D bathymetric model. Migratory routes contained shallower segments, here called 'migratory bottlenecks', which dried out at the end of most lowering-water seasons, blocking the passage to the refuge. Manatees began migrating just in time to traverse the bottlenecks furthest away, suggesting they fine-tuned their departure so as to maximize time within the foraging home range without compromising safety. They apparently achieved this by estimating depth at the bottlenecks. Moreover, a bottleneck was created in $>15$ years, illustrating the environment's dynamism and the challenge this imposes upon manatees. Our results are probably generalizable to most of the species' range. We contend manatees possess an updatable cognitive map of their environment and are behaviorally plastic. Current dam-building plans, if implemented, would create more bottlenecks and make flooding less predictable, increasing manatee mortality from unsuccessful migrations. It would also partition the species into small populations, each prone to short-term extinction. The natural outcome would be the second species-level collapse. Economic growth should not come at the expense of the extinction of the iconic manatee.
\end{abstract}

KEYWORDS: Sirenia, behavioral plasticity, Mamirauá, Amazon development

\section{Gargalos na rota migratória do peixe-boi amazônico e a ameaça das barragens hidrelétricas}

\section{RESUMO}

Em uma região particular da Amazônia ocidental, peixes-boi amazônicos (Trichechus inunguis) vivem em um ambiente que se torna inóspito para eles durante a água-baixa anual. Para fugir dele, realizam uma migração perigosa para o refúgio enquanto o nível da água desce rapidamente. Nosso objetivo foi compreender melhor o papel da variaçáo da profundidade neste processo migratório. Analisamos os únicos dados de rastreamento de peixes-boi selvagens ( $\mathrm{n}=10$ machos), 30 anos de imagens Landsat, 14 anos de hidrógrafa e um modelo batimétrico 3-D. As rotas migratórias possuíam trechos mais rasos, denominados gargalos migratórios, que secaram no final da maioria das vazantes, bloqueando o acesso ao refúgio. Os peixes-boi começaram a migração em tempo justo para atravessar os gargalos mais distantes, sugerindo que a sintonizaram para maximizar o período se alimentando sem comprometer a segurança. Para tal, parecem ter estimado a profundidade nos gargalos. Adicionalmente, um gargalo foi criado em $<15$ anos, ilustrando o dinamismo do ambiente e o desafio que isto impóe aos peixes-boi. Esses resultados provavelmente valem para boa parte da área de distribuição da espécie. Argumentamos que peixes-boi possuem um mapa cognitivo atualizável do ambiente e são comportamentalmente plásticos. Os planos de construção de barragens hidrelétricas, se concretizados, criariam mais gargalos e regimes de inundação menos previsíveis, dificultando a migração e consequentemente aumentando a mortalidade de peixes-boi. Também particionariam a espécie em populaçóes pequenas, vulneráveis à extinção no curto-prazo. $\mathrm{O}$ desfecho seria o segundo colapso da espécie. $\mathrm{O}$ crescimento econômico não deve vir às custas da extinção do icônico peixe-boi.

PALAVRAS-CHAVE: Sirenia, Plasticidade comportamental, Mamirauá, Desenvolvimento Amazônico 


\section{INTRODUCTION}

In the Mamirauá and Amanã Sustainable Development Reserves (RDSM and RDSA, respectively), western Amazonia (Figure 1), Amazonian manatees have two seasonal home ranges between which they migrate (Marmontel et al. 2002). The migration of this exclusively aquatic mammal seems to be a behavioral adaptation to the seasonal changes of the aquatic environment that are brought about by the floodpulse (Arraut et al. 2010 and Figure 2). As explained in Arraut et al. (2010), during the high-water season, when rivers and their floodplains form an interconnected water body, manatees remain within floodplain lakes, where water current is weak and aquatic macrophytes, their main forage, abound. In the low-water season, when most floodplain lakes become shallow and isolated and macrophytes die or go through a terrestrial phase, manatees aggregate in Lake Amanã. Unlike floodplain lakes, Amanã does not dry out, not even in years of extreme droughts, making it a suitable low-water season refuge from stranding or predation (manatees trapped within small water bodies are easy targets for humans, jaguars and other predators). During the low-water season, therefore, taking refuge in Lake Amanã represents the lesser of two evils for manatees.

The lowering-water season migration between floodplain lakes and Lake Amanã occurs when the environment becomes progressively more dangerous for manatees due to the floodplain drying out. Lower water levels make it easier for predators to ambush manatees when they are migrating through the labyrinthian system of narrow channels; in fact, local hunters consider it the best time of the year to kill manatees (Calvimontes 2009).

During a research trip between Lakes Amanã and Mamirauá at the end of the 2005 lowering-water season, reaching Mamirauá by boat became a challenge as both of its entrances (Figure 1, numbers 1 and 2) had dried out completely - we had to drag the boat over mud for about $300 \mathrm{~m}$. This indicated that any manatee that had remained within Lake Mamirauá would have been trapped until water levels rose again a couple of months later. Inspired by this experience, the aim of this study was to better understand the role of depth variation in the manatees' lowering-water season migratory process.

\section{MATERIALS AND METHODS}

\section{Study region}

The study region comprises just over 1 million hectares and lies within RDSM and RDSA, mid River Solimóes region, Amazonas, Brazil (Figure 1). Its $120 \mathrm{~km}$ longitudinal extent (W6503'43.60" - W6351'49.80") includes all locations of the tracked manatees and its $70 \mathrm{~km}$ latitudinal extent
(S02¹4’39.34” - S03³7'45.74) is bounded by várzea and by Lake Amanã. Várzeas are forested floodplains that are bathed by white waters and hence sustain high levels of biodiversity and productivity (Junk 2013). Lake Amanã is a ria, the end section of a river that was naturally dammed by siltation where it reaches the floodplain. A Paraná is a lotic water body that connects two other water bodies (it differs from a river because it has no headspring).

In the várzea of the study region, water levels fluctuate annually up to $16 \mathrm{~m}$, while in Lake Amanã annual variation is about $10 \mathrm{~m}$. Most of this variation is caused by the River Solimóes' floodpulse, which is the principal determinant of the extent and depth of flooding (Figure 2), and of the water's physical-chemistry (Junk et al. 1989). Due to such large variation in water level and the irregular geomorphology of many lakes and canals, water depth is the principal determinant of the connectivity between the water bodies (Figure 2). Based on this habitat seasonality, we distinguish the following seasons: lowering-water (Jul-Aug), low-water (Sep-Nov), rising-water (Dec-Apr) and high-water (May-Jun).

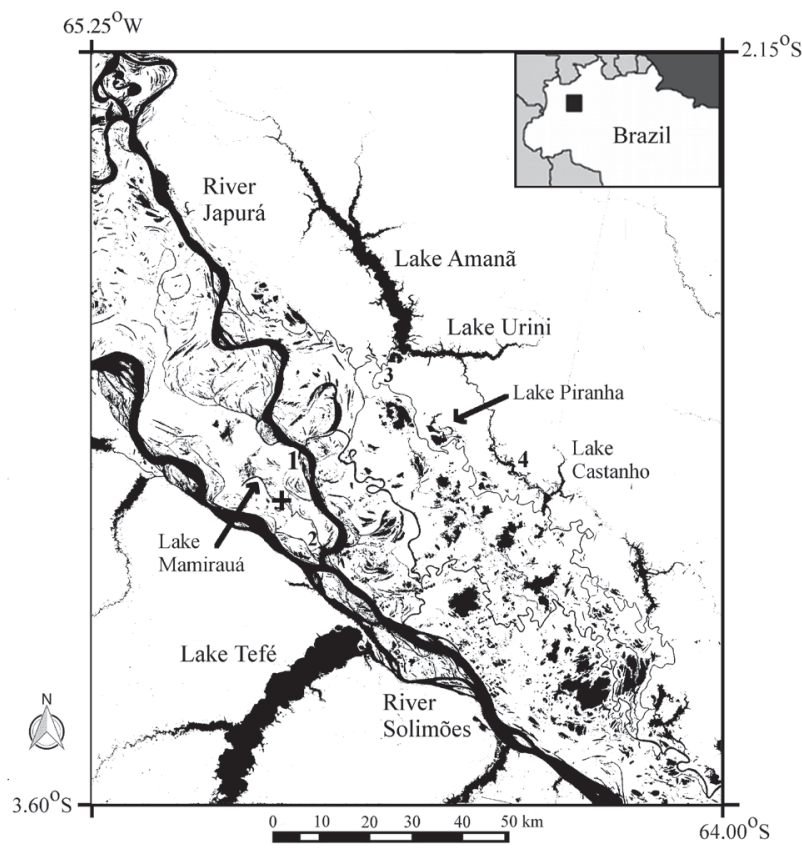

Figure 1. Study area. Shown here are Lakes Mamirauá, Piranha and Castanho, where tracked manatees had their high-water season home ranges, and Lake Amanã, their low-water season refuge from drought and potential predators. Manatees migrated via one of the two narrow channels that connect the floodplain area to Lake Amanã. Numbers indicate locations where bottlenecks 1 to 4 were discovered. A black cross indicates the location of the Mamirauá gauge, where daily water level measurements were carried out. Background image is a Landsat 8 OLI image acquired on 9 September 2015 and converted to black and white. 


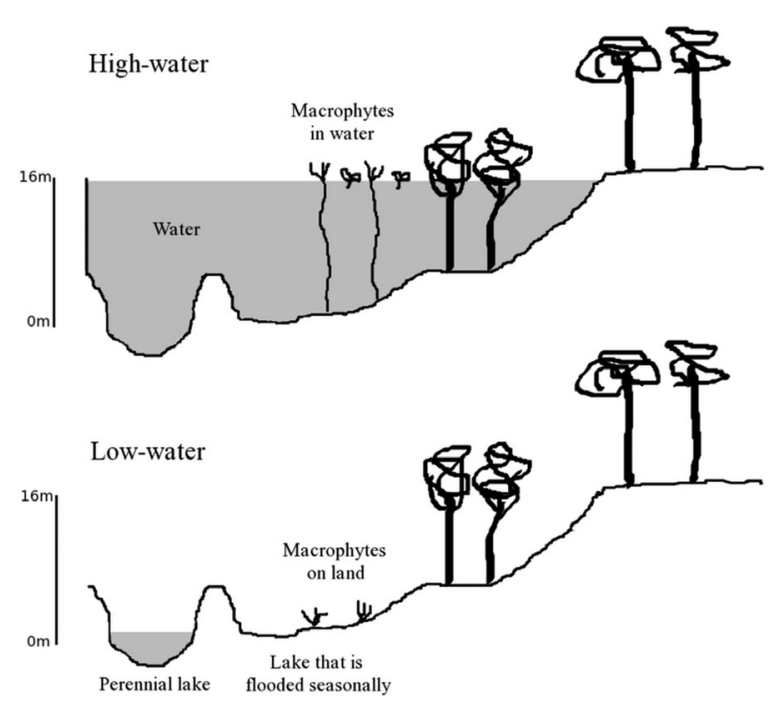

| Floodplain lakes | Floodable forest | Non-floodable forest

Figure 2. Effect of water level variation upon floodplain water bodies. During the high-water season, all water bodies are connected and macrophytes grow in water (floating or rooted). During the low-water season, most floodplain lakes become shallow and isolated and macrophytes either die or go through a terrestrial phase, thus becoming unavailable to manatees.

\section{Data}

Tridimensional bathymetric model - A bathymetric survey was carried out throughout the high- and low-water season ranges and migratory routes of the tracked manatees (Figure 3). A Lowrance 480-M sonar was fixed on the stern of a Zodiac with a $40 \mathrm{HP}$ engine. One person piloted the Zodiac while the other navigated the planned routes. Sampling was done by zigzagging in angles of approximately $45^{\circ}$ and making passages following the contours and thalwegs of the water bodies (see Figure 3). The sampling scheme was planned to allow the creation of a fine-resolution model. Boat speed was kept at $25 \mathrm{~km} / \mathrm{h}$, giving a mean distance between sampling points of about $10 \mathrm{~m}$. Vertical resolution was $1 \mathrm{~cm}$. Lake Amanã was sampled between 29 November 2005 and 3 December 2005, the migration routes on 19 May 2006, and Lake Mamirauá and associated small lakes on 20, 30 and 31 May 2006. In total, sampling took 39 hours.

Data from the eco-sonar survey were checked using Sonarviewer 1.5 (Lowrance 2007). A Matlab algorithm (Matlab 7.1; MathWorks Inc., Natick, Massachusetts, US) was used for: i) extracting the relevant data, ii) transforming coordinates from Lowrance Mercator to Lat/Long, iii) transforming depth values from feet to meters, iv) standardizing depth measurements by means of an empirical equation that considers the variation in the vertical positioning of the sensor as boat speed (with two people onboard) varies (Barbosa 2005), and v) normalizing depth measurements using the 10-year maximum water level

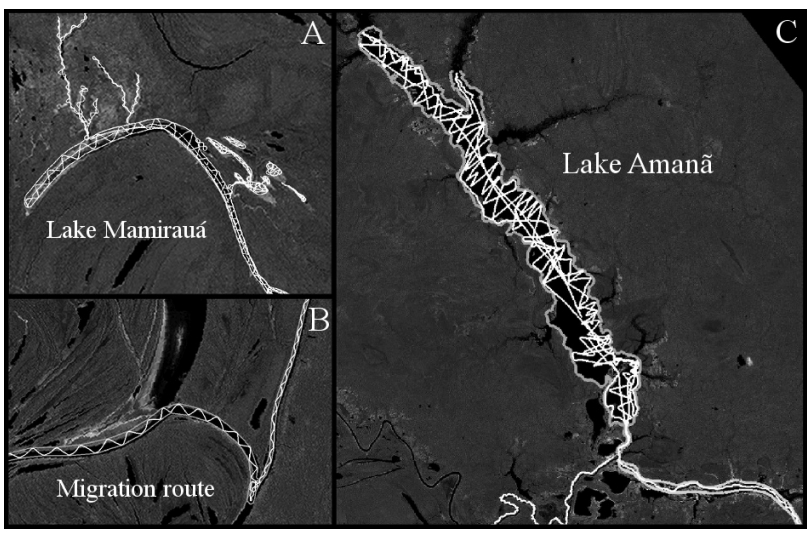

Figure 3. Examples of the sampling scheme followed in the bathymetric survey. Shown here are transects carried out in $A=$ Lake Mamirauá, $B=$ section of migratory route and $\mathrm{C}=$ Lake Amanã.

recorded at the Mamirauá gauge. To allow for error checking, the Matlab algorithm generated separate files for each step. Data were then imported into SPRING 4.3 (Camara et al. 1996) as Digital Terrain Model data type and a second error-checking was carried out. Depth point data were then transformed into a surface using a Delaunay triangulation algorithm. For a set of $\mathrm{P}$ points in a plane, a Delaunay triangulation DT(P) is such that no point in $\mathrm{P}$ is inside the circumcircle of any triangle in $\mathrm{DT}(\mathrm{P})$ - it maximizes the minimum angle of all the triangles' angles (Delaunay 1934). To create the boundaries for constraining triangulation in places where edges of water bodies had not been sampled in the field, a Landsat-TM image was used as background and the values sampled by the sonar in the nearest margin (usually 20-50m away) were attributed to those places. Finally, the triangulated surface was transformed into a $15 \times 15 \mathrm{~m}$ grid using a regular grid function. A routine in SPRING's programming language, LEGAL, allowed for changing the reference water level in the model to the water level on any particular day of interest, e.g. the peak of a certain year's low-water season (Figure 4).

Historical dataset of satellite images - In Landsat TM visible and infra-red bands, the spectral reflectances of water, shallow areas (where the signal is a mixture of the underlying soil and water), and dry land are notably different (Jensen 2006). This indicated that these images could be used to assess whether segments within the migration routes dried out and changes in routes occurred during the period covered by the image data. We compiled 36 years (1975 to 2011) of Landsat-MSS, TM and ETM+ images that were acquired at, or very close to, the day of the low-water season's peak each year. Radiometric correction for reducing haze in each band, followed by resampling to $15 \mathrm{~m}$ spatial resolution for improving recognition of small features, was performed using the restoration algorithm (Fonseca 1988) in SPRING (Camara et al. 1996). 


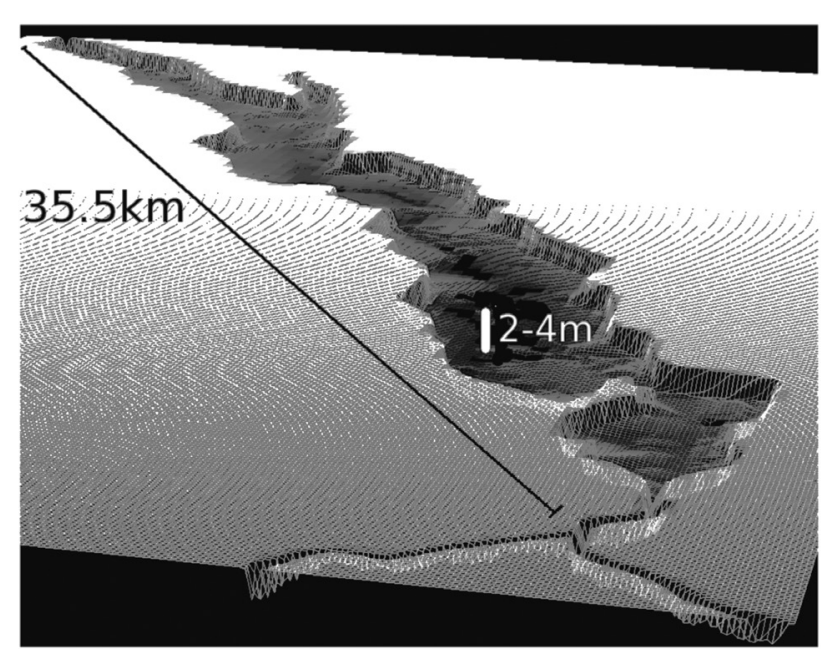

Figure 4. Tridimensional visualization of Lake Amanã's bathymetric model, calibrated for the peak of the 2005 low-water season. The model shows that, even in the 2005 extreme drought, Amanã offered ample aquatic space for manatees. The value $2-4 \mathrm{~m}$ indicates depth variation throughout Amanã, with deeper areas appearing darker (vertical scale exaggerated for visualization purposes).

Visual inspection showed no geomorphological processes causing significant changes to areas other than the one where a new bottleneck was created (see Results). Therefore, the routes' depth profile in 2005-2006, when the bathymetric data were collected, was considered a good approximation for the depth profile when the manatees migrated.

VHF radio-tracking of manatees - We used the single existing dataset for Amazonian manatees' movements in the wild (Table 1). The 13 manatees on which VHF transmitters were fixed were caught under government permit by research teams, sometimes aided by local hunters, mostly using a wide mesh net. Of the three captured females, we lost track of two on the day after capture and one was found dead two days after collaring. Thus, our sample consisted of 10 males, which we tracked from 1994 to 2006 (excepting 2004) using Advanced Telemetry Systems (ATS) transmitters on the $164 \mathrm{MHz}$ band and using 3-element Yagi antennas: one handheld and one fixed to the top of a tower close to the mouth of Lake Mamirauá - the latter captured the moment that manatees left Lake Mamirauá (Table 3).

Though hunting of Brazilian native fauna is illegal (Brasil 1967), hunters eventually killed six out of the ten tracked males. We later came to believe hunters inferred their approximate whereabouts by observing the tracking team's movements. This led us to invest more time in establishing good relationships with local hunters, which might explain why the young manatee released in 2015 was not killed, despite its vulnerable situation (paragraph 3, Discussion).
Table 1. Data on tracked manatees. $M=$ Male, $F=$ Female, $L$. $=$ Lake and $\mathrm{P}$. = Paraná. Seasons refer to water level seasons as used throughout text. Tracking within tracking period was sometimes irregular.

\begin{tabular}{|c|c|c|c|c|c|c|}
\hline \multirow[b]{2}{*}{ ID } & \multirow[b]{2}{*}{ Gender } & \multicolumn{3}{|c|}{ Captured } & \multirow[b]{2}{*}{$\begin{array}{l}\text { Tracking } \\
\text { period }\end{array}$} & \multirow[b]{2}{*}{$\begin{array}{l}\text { Reason it } \\
\text { stopped }\end{array}$} \\
\hline & & Place & Season & Date & & \\
\hline 1 & M & L. Mamirauá & high & $20 / 06 / 96$ & $4 y$ & Disappeared \\
\hline 2 & M & L. Mamirauá & high & 28/06/95 & $3 y 4 m$ & Hunted \\
\hline 3 & M & L. Mamirauá & high & $14 / 07 / 95$ & $4 y 4 m$ & Hunted \\
\hline 4 & M & L. Amanã & low & $12 / 11 / 01$ & 1y $4 \mathrm{~m}$ & Hunted \\
\hline 5 & $M$ & L. Amanã & low & 29/11/05 & $5 m$ & Disappeared \\
\hline 6 & $M$ & $\begin{array}{c}\text { P. do } \\
\text { Castanho }\end{array}$ & lowering & $18 / 08 / 97$ & $3 y$ & Disappeared \\
\hline 7 & M & L. Mamirauá & high & $26 / 06 / 95$ & $2 \mathrm{y} 2 \mathrm{~m}$ & Disappeared \\
\hline 8 & M & L. Amanã & low & $11 / 11 / 01$ & $3 m$ & Hunted \\
\hline 9 & M & L. Amanã & low & $11 / 11 / 01$ & $3 m$ & Hunted \\
\hline 10 & M & L. Amanã & low & $10 / 10 / 05$ & $6 m$ & Hunted \\
\hline 11 & $F$ & $\begin{array}{c}\text { P. do } \\
\text { Castanho }\end{array}$ & lowering & 18/08/97 & $\begin{array}{c}\text { not } \\
\text { tracked }\end{array}$ & Disappeared \\
\hline 12 & $\mathrm{~F}$ & $\begin{array}{c}\text { P. do } \\
\text { Castanho }\end{array}$ & lowering & $18 / 08 / 97$ & $\begin{array}{c}\text { not } \\
\text { tracked }\end{array}$ & Disappeared \\
\hline 13 & $\mathrm{~F}$ & $\begin{array}{c}\text { P. do } \\
\text { Castanho }\end{array}$ & lowering & 28/08/05 & $\begin{array}{c}\text { not } \\
\text { tracked }\end{array}$ & Found dead \\
\hline
\end{tabular}

\section{Analyses}

Blocking of manatees' migration by closure of migratory bottlenecks - To estimate the depth at a bottleneck when traversed by a tracked manatee, we: i) recorded the day the manatee began migrating, ii) estimated how many days later he would have reached the bottleneck by assuming he travelled at a constant speed of $31.5 \mathrm{~km} /$ day, which corresponded to the travelling speed of the adult male for whom we had the best tracking information (he travelled $115 \mathrm{~km}$ between Lakes Mamirauá and Amanã in 2.08 days), and then iii) used the hydrograph information to calibrate the bathymetric model so that it reflected the depth at a bottleneck on the day that the manatee would have traversed it. We assumed that a manatee would only traverse a bottleneck that was $>=0.5 \mathrm{~m}$ deep at its thalweg. This is a conservative assumption because: i) the diameter of an adult manatee is usually greater than $0.5 \mathrm{~m}$ and a manatee would only attempt to traverse a bottleneck by crawling if it were fleeing from immediate danger, and, ii) owing to the V-shaped cross-sectional depth profile of bottlenecks, even before reaching the $0.5 \mathrm{~m}$ depth mark a bottleneck would already have become a narrow and shallow canal that a manatee would most likely avoid traversing. We also calculated how many times each of the four bottlenecks 
would have closed if uncertainty in our bathymetric modeling were of the order of $\pm 1 \mathrm{~m}$. Such uncertainty could stem, for example, from differences in the dates between when the echosonar census was carried out and when manatees were tracked.

Relationship between depth-related variables and the initiation of migration - Since there exists little information regarding manatees' spatial and temporal perception of the environment, we chose not to rule out, a priori, the possibility that they had the ability to interpret different kinds of signals or make estimations. Thus, to answer our questions we analyzed all possible unambiguously identifiable measurements of depth or its variation between the high- and low-water seasons, i.e., those associated with the hydrograph's singularities.

$\mathrm{M}_{\mathrm{y}}, \mathrm{m}_{\mathrm{y}}$ and $\mathrm{I}_{\mathrm{y}}$ denoted the depth at the Mamirauá gauge when, in year $y$, the hydrograph reached its maximum, minimum and absolute inflection points (the absolute minimum of the first derivative of the hydrograph), respectively. If one positions a gauge at a given location in a water body within the floodplain, the hydrograph obtained from this gauge will correspond to a vertical translation of the Mamirauá hydrograph. Therefore, the Mamirauá hydrograph was suitable to analyze variation in depth at any given location within the study region.

We denoted the high-water season home ranges by $\mathrm{H}_{h}$ and the low-water season home ranges by $\mathrm{H}_{1}$. We then considered the experiment whose outcomes are represented by the ordered pairs $\left\{\left(T_{i}, d_{i v}\right) ; 1 \leq i \leq 8\right.$ and $\left.1995 \leq y \leq 2002\right\}$, where $T_{i}$ denoted one of the eight VHF tracked manatees and $d_{i y}$ the day of the year $y$ in which $T_{i}$ initiated its loweringwater season migration by leaving $\mathrm{H}_{\mathrm{hi}}$. We then let $\mathbf{A}$ be the random variable that associated to $\left(\mathrm{T}_{\mathrm{i}}, \mathrm{d}_{\mathrm{iy}}\right)$ the depth $\mathrm{A}_{\mathrm{iy}}$ of the Mamirauá gauge on the day $\mathrm{d}_{\mathrm{iy}}$. Based on this, we defined variables $\mathbf{A}, \mathbf{B}=\mathrm{M}_{\mathrm{y}}-\mathbf{A}, \mathbf{C}=\mathbf{A}-\mathrm{m}_{\mathrm{y}}$ and $\mathbf{D}=\mathbf{A}-\mathrm{I}_{\mathrm{y}}$. Each of these variables represented a hypothesis of what might have triggered the migration of manatees.

The question was which depth-related estimate could manatees have used to decide when to commence migration. The hypothesis was that the variable potentially used by them would be that which presented the smallest variation among individuals. In order to test this, the absolute deviations from the means of $\mathbf{A}, \mathbf{B}, \mathbf{C}$ and $\mathbf{D}$ were compared by means of a bootstrap approach. One thousand samples of size 11 were created and their variances estimated. Then, pairwise comparisons of the variances were carried out, recording, in each comparison, the variable that presented the smallest variance. The null hypothesis was $\operatorname{Var} \mathrm{X} \geq \operatorname{Var} \mathrm{Y}$. This gave the proportion of times in 1000 trials that each variable presented a smaller absolute deviation from the mean with respect to each one of the others.

\section{RESULTS}

Along manatees' migratory routes, we identified four shallow stretches that were the first to dry out when water levels receded. These segments, which we called 'migratory bottlenecks', varied in length from about $800 \mathrm{~m}$ to just over $10 \mathrm{~km}$ (Figure 5 shows the shortest and longest bottlenecks that were identified).

An assessment of how often the passage to the low-water season refuge was blocked throughout 14 years revealed that bottlenecks 1, 3 and 4 closed either every year or almost every year, whilst bottleneck 2 closed twice (Table 2). Considering an error of $-1 \mathrm{~m}$, bottleneck 1 blocked 13 times, bottlenecks 3 and 4 nine times, and bottleneck 2 did not impede their passage. Considering an error of $+1 \mathrm{~m}$, bottlenecks 1,3 and

Table 2. Drying out of migratory bottlenecks between the years 1992 and 2005 (identified by same numbers as in Figures 1 and 5). Bold indicates bottlenecks that closed that particular year (see Methods). Minimum water level (meters) as registered by Mamirauá gauge (location shown in Figure 1). The depth across a river usually varies, so shown here are maximum bottleneck depth (negative) or height of dried out riverbed (positive) during low-water season peak, separated between the lowest (low) value found in the bottleneck and highest (high) value found in the cross section where the lowest was obtained. Combined, these values give an idea of the variation in the relief of the bottleneck where danger for manatees is potentially greater. *Data for 1992 starts on 11 November so may not represent lowest water level that year.

\begin{tabular}{|c|c|c|c|c|c|c|c|c|c|}
\hline \multirow[b]{2}{*}{ Year } & \multirow{2}{*}{$\begin{array}{c}\text { Min water } \\
\text { level }\end{array}$} & \multicolumn{8}{|c|}{ Bottlenecks } \\
\hline & & $\begin{array}{c}1 \\
\text { low }\end{array}$ & $\begin{array}{c}2 \\
\text { low }\end{array}$ & $\begin{array}{c}3 \\
\text { low }\end{array}$ & $\begin{array}{c}4 \\
\text { low }\end{array}$ & $\begin{array}{c}1 \\
\text { high }\end{array}$ & $\stackrel{2}{2}$ & $\begin{array}{c}3 \\
\text { high }\end{array}$ & $\begin{array}{c}4 \\
\text { high }\end{array}$ \\
\hline $1992^{*}$ & 4.0 & 1.4 & -3.4 & -0.2 & -0.1 & 1.5 & 4.0 & 0.5 & 1.5 \\
\hline 1993 & 4.7 & 0.8 & -4.1 & -0.8 & -0.7 & 0.9 & 3.4 & -0.1 & 0.9 \\
\hline 1994 & 4.6 & 0.8 & -4.0 & -0.8 & -0.7 & 0.9 & 3.4 & -0.1 & 0.9 \\
\hline 1995 & 0.6 & 4.9 & 0.1 & 3.3 & 3.4 & 5.0 & 7.5 & 4.0 & 5.0 \\
\hline 1996 & 2.5 & 3.0 & -1.8 & 1.4 & 1.5 & 3.1 & 5.6 & 2.1 & 3.1 \\
\hline 1997 & 2.2 & 3.2 & -1.6 & 1.6 & 1.7 & 3.3 & 5.8 & 2.3 & 3.3 \\
\hline 1998 & 1.6 & 3.9 & -1.0 & 2.3 & 2.4 & 4.0 & 6.5 & 3.0 & 4.0 \\
\hline 1999 & 2.3 & 3.2 & -1.7 & 1.6 & 1.7 & 3.3 & 5.8 & 2.3 & 3.3 \\
\hline 2000 & 0.8 & 4.7 & -0.2 & 3.1 & 3.2 & 4.8 & 7.3 & 3.8 & 4.8 \\
\hline 2001 & 1.8 & 3.7 & -1.2 & 2.1 & 2.2 & 3.8 & 6.3 & 2.8 & 3.8 \\
\hline 2002 & 2.8 & 2.6 & -2.2 & 1.0 & 1.1 & 2.7 & 5.2 & 1.7 & 2.7 \\
\hline 2003 & 4.0 & 1.4 & -3.4 & -0.2 & -0.1 & 1.5 & 4.0 & 0.5 & 1.5 \\
\hline 2004 & 5.2 & 0.3 & -4.5 & -1.3 & -1.2 & 0.4 & 2.9 & -0.6 & 0.4 \\
\hline 2005 & 2.1 & 3.4 & -1.5 & 1.8 & 1.9 & 3.5 & 6.0 & 2.5 & 3.5 \\
\hline
\end{tabular}




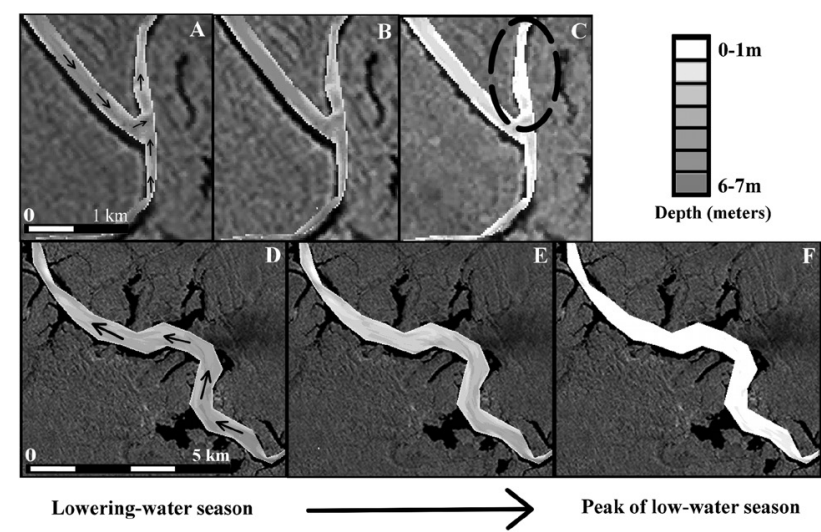

Figure 5. Drying out of bottlenecks $3(A-C)$ and 4 (D-F); for their locations, see Figure 1. Shown here are the depths on the day that a manatee began migrating (panels $A$ and $D$ ), traversed that particular bottleneck (panels $B$ and E), and at the peak of the 2005 low-water season (panels $C$ and F). Black arrows in panels $A$ and $D$ show migratory trajectories of manatees traversing these bottlenecks. The dashed oval in panel $\mathrm{C}$ shows location of bottleneck 3. Bottleneck 4 is the entire Lake Castanho. Background is a Landsat band 4 image acquired on 29 August 1997 (tones of gray indicate forest, while water appears black).

4 blocked every year and bottleneck 2 closed five times. Bottlenecks remained dry from the end of the lowering-water season to the beginning of the following rising-water season (roughly 2 months).

Our analysis also revealed a migratory bottleneck being created and the process by which this happened. Lake Urini, which connects one of the migratory routes to Lake Amanã and was roughly as deep as Amanã in the early 1990's, became a 5 -km long migratory bottleneck in about 15 years (Figures 6 and 7). This was caused by intense siltation (Figure 6).

The analysis of manatee movements revealed that, during the high-water season, only one individual, and on one occasion, came close to a bottleneck before migrating (the temporal tracking resolution was too low to allow for distinguishing whether he actually visited the bottleneck): individual 1, which spent the 1995 high-water season in Lake Mamirauá, was located $<500 \mathrm{~m}$ from bottleneck 2 (see Figure 1), remained at this location for about six hours on 24-25 July 1995 (10:01 pm to 3:40am), returned to Lake Mamirauá for nine days and, finally, traversed bottleneck 2 again on 2 August 1995 when migrating out from Mamirauá. The other recorded migrations ( $\mathrm{n}=10)$ began abruptly - after a few months within $\mathrm{H}_{\text {hi }}$, each individual began a directed
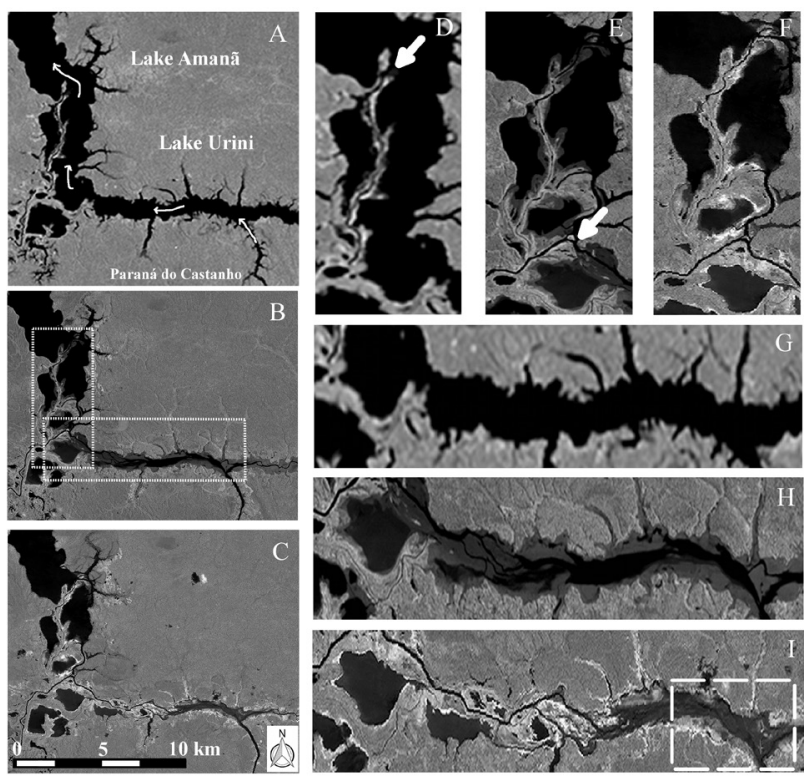

Figure 6. Creation of the Lake Urini migratory bottleneck (A-C) in less than 15 years, a time span that is well within a manatee's potential lifespan. White arrows in panel A indicate manatee's migratory route via Paraná do Castanho and Lake Urini into Lake Amanã, which was used by individuals spending the high-water season in Lakes Piranha and Castanho (see Figure 1). Dotted rectangles in B delimit areas shown in panels D-F and G-I. White arrows in panels D-F indicate the change in location of the mouth of Paraná do Amanã. This resulted in a shift, from Lake Amanã to Lake Urini, of the discharge of the sediment from River Solimões brought by Paraná do Amanã. Panels G-I show the siltation happening in Lake Urini (water appears black, land covered by a thin layer of water or wet mud appear in dark grey, dry land or forest appear in lighter grey, while macrophytes growing on dry land appear white). Notice how, during the low-water season, Lake Urini changed from the wide lake it used to be in 1979 (G) to a long, narrow and shallow channel by 2005 (I). In 2005, several manatees were not able to reach the safety of Lake Amanã because they arrived at the mouth of Lake Urini after it had dried out (see Figure 7) (panel I). Images are Landsat MSS from 16/9/1979 (A, D and G), and Landsat TM from 1/11/1991 (B, E and H) and 6/10/2005 (C, F and I). The dashed rectangle in I indicates the area shown in the aerial photo presented in Figure 7.

movement out of Mamirauá. All departures took place when water levels varied within a narrow range of $1.12 \mathrm{~m}$ (Table 3 ).

Analysis also showed that variable A (Mean $=9.14 \mathrm{~m}, \mathrm{SD}$ $=0.39 \mathrm{~m} ; \mathrm{n}=11)$ presented the smallest absolute deviation (Table 4), suggesting that a simple local measurement of absolute depth was the signal most closely associated with the initiation of migration. It was also worth noting that $A_{\text {iy }}$ always occurred before $I_{y}$, showing that manatees left when the speed at which the environment was becoming inhospitable was still increasing. 


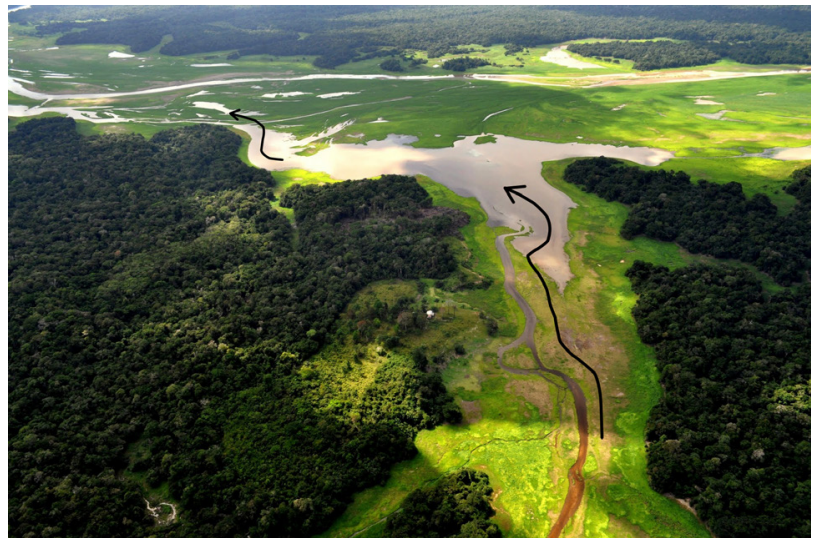

Figure 7. Aerial photo of the end section of Paraná do Amanã and part of the Lake Urini bottleneck (photo area delimited by the dashed white rectangle in Figure 6, panel I, and black arrow showing the same migratory trajectory that is depicted in Figure 6, panel A). This photo was taken on 22 October 2010, within a week of the peak of the 2010 low-water season in the area. Manatees that did not traverse this bottleneck before it dried out remained trapped during the entire low-water season in the very narrow and shallow canal that remained between Lake Urini and Lake Castanho bottlenecks (shown just to the left of the larger black arrow). This figure is in color in the electronic version.

Table 3. Data on 11 departure timings of lowering-water migrations. Y-Max, Y-Min and Y-IP stand for, respectively, maximum and minimum water level of the year, and water level on day of inflection point that year. Different times of departure suggest individuals initiated migration independently.

\begin{tabular}{lcccccc}
\hline ID & Date & Time & $\begin{array}{r}\text { Water level at } \\
\text { departure }(\mathrm{m})\end{array}$ & Y-Max & Y-Min & Y-IP \\
\hline 1 & $2 / 8 / 95$ & $15: 00$ & 8.51 & 11.68 & 0.59 & 5.08 \\
\hline 2 & $2 / 8 / 95$ & $13: 40$ & 8.51 & 11.68 & 0.59 & 5.08 \\
\hline 3 & $25 / 7 / 95$ & $23: 05$ & 9.63 & 11.68 & 0.59 & 5.08 \\
\hline 1 & $1 / 8 / 96$ & $16: 15$ & 9.48 & 13.13 & 2.45 & 5.61 \\
\hline 2 & $2 / 8 / 96$ & $21: 35$ & 9.32 & 13.13 & 2.45 & 5.61 \\
\hline 3 & $2 / 8 / 96$ & $12: 20$ & 9.32 & 13.13 & 2.45 & 5.61 \\
\hline 4 & $2 / 8 / 96$ & $21: 50$ & 9.32 & 13.13 & 2.45 & 5.61 \\
\hline 2 & $13 / 8 / 97$ & $10: 30$ & 8.91 & 14.86 & 2.22 & 2.98 \\
\hline 3 & $13 / 8 / 97$ & $10: 30$ & 8.91 & 14.86 & 2.22 & 2.98 \\
\hline 5 & $28 / 7 / 00$ & $00: 00$ & 9.04 & 11.40 & 0.79 & 5.03 \\
\hline 6 & $28 / 8 / 02$ & $06: 30$ & 9.58 & 13.43 & 2.82 & 7.74 \\
\hline
\end{tabular}

Table 4. Pairwise comparisons of variables A, B, C and D. Variable A, which represents a simple local measurement of depth, presents significantly smaller inter-individual variability when compared pairwise to all others using a bootstrap approach.

\begin{tabular}{ll}
\hline Comparison & $P$ \\
\hline$A>=B$ & 0.008 \\
$A>=C$ & 0.006 \\
$A>=D$ & 0.025 \\
$B<=$ C & 0.096 \\
$B<=$ D & 0.397 \\
C $>=$ D & 0.148 \\
\hline
\end{tabular}

\section{DISCUSSION}

We have shown that there are migratory bottlenecks that manatees need to traverse in order to reach their low-water season refuge from drought and predation (Figures 5, 6 and 7). The four identified bottlenecks dried out more often than not during our study period (Table 2), showing they are important migratory obstacles. Failing to traverse these obstacles implies having to spend the low-water season: i) within a small and shallow floodplain lake, ii) between two closed migratory bottlenecks, or iii) within one or more lotic water bodies. In the first two situations, the water bodies can end up drying out completely, while, in the latter case, manatees either need to invest considerable energy into fighting water currents during the (approximately) two months of the scarce-forage low-water season or have to confine their use of space to small backwaters, where they become vulnerable to terrestrial predators.

Additionally, our analysis showed that migratory bottlenecks may be created in time-scales well within the potential lifespan of a manatee (Figure 6). This implies that yearly survival is closely associated with the ability to monitor changes to bottlenecks and adjust departure timing accordingly. Importantly, the creation of the bottleneck shown here is a mere illustration of how dynamic the floodplain environment is. Owing to natural geological, geomorphological and hydrological processes that operate on several temporal and spatial scales, the floodplain has undergone much more profound changes during the 6 million years since the ancestral trichechid entered the Amazon (Domning 1982a). When such 
changes affected the entire species' range and were long-lasting, morphological adaptations took place. This was the case, for example, with the transition of the manatees' inferred diet from seagrasses to more abrasive freshwater macrophytes when the upper Amazon basin became isolated from the Caribbean Sea (10-7 million years ago). The manatees' lineage adapted by developing supernumerary molars that are continually replaced throughout life (Domning 1982a). On the other hand, when changes have occurred on time scales of decades or a few hundred years and have been spatially heterogeneous, adaptations must have been predominantly behavioral. This was the case with the use of rias (such as Lake Amanã) as lowwater season refuges, since these were created in the last 43,700 years (Rossetti et al. 2005). Another example of this was with the use of present-day floodplain lakes and migration routes, as these may change within only a few hundred years or even decades (Mertes 1994; Mertes et al. 1996). Additionally, extant manatees living near the mouth of the Amazon (Domning 1981) have no access to rias (these do not exist there) and need to cope with water levels varying in concert with the tidal rhythm of the Atlantic Ocean. Yet, these animals are part of the same panmictic population as those living within our study area (Satizábal et al. 2012). From the above, one concludes that manatees are behaviorally plastic, in the sense that a single genotype can produce more than one form of behavior in response to environmental conditions (WestEberhard 1989).

We speculate that transmission of information regarding migration routes and departure timing is initially matrilineal. Calves spend their first two years with the cow (Rosas 1994), and, although no females have been tracked, information from hunting (Thornback and Jenkins 1982), and estimates of when and where calving occurs (Best 1982), suggest females have similar seasonal movement patterns to males. Matrilineal transmission of knowledge about migration routes, seasonal home ranges and location of key resources has been documented, for example, in the Florida manatee Trichechus manatus latirostris (Deutsch et al. 2003). In Amazonian manatees, who become solitary after weaning (Rosas 1994), migrating successfully throughout life requires either: 1) following a more knowledgeable manatee, or 2) learning enough about the environment's dynamics to decide alone when to begin migrating and which route to take. Interestingly, both situations find support in a recent case in which a male manatee, rescued as a calf and rehabilitated over seven years in Lake Amanã, was released within this same lake. In the 2015 rising-water season, he migrated into the floodplain, probably following other individuals that had aggregated within the refuge during the low-water season. However, he missed the following lowering-water season migration back into the refuge and ended up becoming trapped between the Urini and Castanho bottlenecks (Marmontel et al. unpubl. data). If, owing to a long-term collaboration, local villagers had not refrained from hunting tracked manatees, he could have been easily killed.

With regard to the triggering of migration, our analysis demonstrates that a manatee could annually traverse bottlenecks successfully if it were able to relate a measurement of depth or its variation within $\mathrm{H}_{h}$ to an estimate of depth at bottlenecks. All individuals began migrating when $\mathrm{H}_{h}$ still offered ample aquatic space and forage, and with the exception of one manatee that may have made an excursion to the nearest bottleneck just over a week before migrating past it again (see Results), all other individuals seem to have departed without recent knowledge of the state of the bottlenecks. This suggests that the motivation to leave came from events occurring outside of $\mathrm{H}_{\mathrm{h}}$. A simple yet plausible scenario would be that manatees tracked the receding water levels until a reference height was reached, and, by relating that to depth at bottlenecks, decided when to depart. Such reference could be the drying out of a particular tree branch or stretch of land within $\mathrm{H}_{\mathrm{h}}$. This scenario requires manatees to possess near-field vision and a cognitive map of their environment (i.e. a mental image). Though, to our knowledge, the visual capabilities of this species have not been studied, Florida manatees have been shown to possess good color (likely dichromatic) vision (Griebel and Schmid 1996). As for the cognitive map, mammals varying from lab rats (Fyhn et al. 2004; Kjelstrup et al. 2008), to red deer Cervus elaphus (Gautestad and Mysterud 2013) and African elephants Loxodonta africana (Polansky et al. 2015) have been shown to either have or behave in ways that could so far only be explained by their having such a map. In Sirenia, the existence of mental mapping abilities is suggested by the fact that both Florida manatees and dugongs Dugong dugon make directed migratory movements, usually exploring the same stop-over sites, in the latter case across hundreds of kilometers of deep open waters (Deutsch et al. 2003; Sheppard et al. 2006). As a matter of fact, technical and theoretical advancements in the study of animal movements have been showing that such mapping abilities seem to be common among mammals (Powell and Mitchell 2012).

The above interpretation of what triggers manatees' migration needs to be considered with caution for at least three reasons: small tracking sample size, lack of tracked females, and the possibility that other variables influence triggering. This said, as the selective pressures imposed by the drying out of the floodplain affect both sexes and all age classes alike, we suspect that the basic triggering mechanisms presented here may apply to all individuals. It is, nonetheless, vital to increase the sample. With regard to other cues, it is improbable that Amazonian manatees use water temperature, as Florida manatees do (Deutsch et al. 2003), or daylight duration, as 
many species of birds that spend summer in high latitudes do (Farner 1986), because these vary little in the equatorial Amazon. It is, however, also conceivable that alternative signals are used. One such example is the changes in water turbidity that take place somewhat predictably within floodplain lakes (Barbosa et al. 2009). One must bear in mind, however, that relying primarily on a signal other than depth would only be efficient if its variation within $\mathrm{H}_{\mathrm{hi}}$ were strongly correlated with the depth at bottlenecks - after all, it is the lack of depth and associated problems that kills manatees. Such association does not seem to exist in the case of siltation because it is a localized process (Mertes 1994 and Figure 6). Thus, while other signals may be important, and perhaps even visits to nearby bottlenecks prior to departure may be relevant (see Results), we conjecture that the main trigger involves relating depth within $\mathrm{H}_{\mathrm{h}}$ to depth at bottlenecks.

That manatees traversed migratory bottlenecks just a few days before these dried out (Figure 5) suggests they delayed departure as much as possible. This would be advantageous because it would allow them to forage for longer within $\mathrm{H}_{h}$ prior to withstanding the scarce-forage low-water season (Arraut et al. 2010; Guterres-Pazin et al. 2014). The risk of reaching the refuge with low fat reserves is exemplified by manatees in Lake Amanã having been reported as dying in distinctly emaciated condition (thin and lacking internal and external fat reserves) at the end of the low-water season (Best 1983). Dugongs make an analogous food-safety trade-off (Wirsing et al. 2007), though for them the choice is between a good-forage-high-risk area and a low-forage-low-risk area. For manatees, for whom forage is scarce in both areas, their migration seems to be fine-tuned so as to maximize energy uptake without compromising safety.

Information from sightings, killings, slaughters and carcasses indicate that manatees living elsewhere in lowland floodplains have similar movement patterns to those tracked herein. For example, manatees spend the low-water season in lakes Manacapurú, Coari, Badajós and Tefé (which, like Lake Amanã, are rias), but are usually not found there during the high-water season (Thornback and Jenkins 1982), which suggests they emigrate from these areas as water levels increase. The regions of the floodplain where these other lakes are located are geomorphologically and hydrologically similar to our study area (Mertes et al. 1994), thus making it likely that manatees living in these other areas also have to traverse bottlenecks on their way to their low-water season refuges. Confirming this requires expanding studies of wild manatees and their environment to those areas.

As migratory bottlenecks create a direct connection between the ecosystem's flooding dynamics and the fate of manatees, the extensive program of large dam construction planned for the Amazon Basin, which is considered as the main threat to Amazonian wetlands and their biodiversity in the coming decades (Junk 2013), generates profound concern for the conservation of manatees. Within the region, there are 154 large dams in operation, 21 under construction and 102 at planning stage (Castello and Macedo 2015). For manatees, such dam-building plans are perilous because every additional dam partitions the population - partitioning is into $\mathrm{n}+1$ parts, $n$ being the number of dams within the species' range. Each small population then suffers from inbreeding, loss of evolutionary potential, increased likelihood of extinction from stochastic processes, and greater vulnerability to slaughter, especially during droughts (Arraut and Marmontel 2016). Furthermore, as dams operate to maximize energy production, in years of extreme climatic droughts one may expect extreme hydrological droughts to be even more intense downstream of such dams. This would lead to an even drier floodplain, as well as to more migratory bottlenecks separating manatees from their low-water season refuges, both of which would lead to increased manatee mortality. The situation would be further aggravated considering that dam-building degrades local socio-environmental conditions (Silva et al. 2012); and our experience shows that this invariably results in increased manatee slaughtering. In summary, an Amazon basin packed with dams would be a perfect setting for pervasive local extinctions of the small and isolated manatee populations. The manatee's first species-level population collapse happened after 200 years of commercial exploitation (Domning 1982b), and here we contend that current development plans for the Amazon will lead to the second collapse.

\section{CONCLUSIONS}

The migration routes of manatees include shallower segments that dried out completely towards the end of most lowering-water seasons, blocking the passages to the low-water season refuge from drought and predation. Additionally, bottlenecks change on time scales well within the potential lifespan of manatees, implying that to continue migrating successfully throughout their lives these animals need to behaviorally adapt to such changes. Preliminary evidence suggests that manatees may use a cognitive map of their environment to relate depth within $\mathrm{H}_{\mathrm{hi}}$ to depth at bottlenecks, and we conjectured that such depth monitoring constitutes the main signal manatees use to decide when to begin migrating. Worryingly, if the current massive hydroelectric dam-building plans for the Amazon actually materialize, manatees will need to face an environment in which flooding dynamics are less predictable, further increasing their migratory challenge. Moreover, in years of climate- or dam-induced extreme droughts, migratory bottlenecks would become longer and more frequent, leading to more manatees dying from being stranded or from hunting. Finally, as dams degrade and divide 
the aquatic environment, the present-day manatee population would be partitioned into myriad small and isolated populations that would become vulnerable to short-term extinction. The natural outcome would be the second species-level population collapse, which would likely put the species on a direct path to near-term extinction in the wild. For the reasons stated above, our final point is: the current development plan for the Amazon needs to be urgently revised, as the pursuit of economic growth by South America in general, and Brazil in particular, should not come at the expense of the extinction of the Amazonian manatee, an iconic, ecologically and culturally important animal whose ancestral colonized the region 6 million years ago.

\section{ACKNOWLEDGMENTS}

We are grateful to CAPES, GEOMA Network, Graduate program in Remote Sensing at INPE (Brazil), National Institute of Science and Technology for Climate Change (INCT-MC), Brazilian National Research Council (CNPq) and Oxford University. We are thankful to Antonio Pinto Oliveira for his assistance during fieldwork, and to all local hunters and trainees who helped with data collection. We are grateful to Thiago Figueiredo for having granted permission to use the photo shown in Figure 7. We also thank Camilo Rennó, Silvia Moraes, Josefina Moraes Arraut, Robert Kenward, the associate editor and three anonymous reviewers for helpful comments.

\section{REFERENCES}

Arraut, E.M.; Marmontel, M.; Mantovani, J.E.; Novo, E.M.L.M.; Macdonald, D.W.; Kenward, R.E. 2010. The lesser of two evils: seasonal migrations of Amazonian manatees in the Western Amazon. Journal of Zoology, 280: 247-256.

Arraut, E.M.; Marmontel, M. 2016. Amazonian manatee threatened with extinction by massive dam-building plan in the Amazon. Response to Winemiller et al. 2016. Science, 351: 128-129. (http://science.sciencemag.org/content/351/6269/128.e-letters)

Barbosa, C.C.F. 2005. Sensoriamento remoto da dinâmica da circulaçâo da água do sistema planície de Curuai/Rio Amazonas. Tese de Doutorado, Instituto Nacional de Pesquisas Espaciais, São José dos Campos, SP. 255p.

Barbosa, C.C.F.; Novo, E.M.L.M.; Melack, J.M.; Gastil-Buhl, M.; Filho, W.P. 2009. Geospatial analysis of spatiotemporal patterns of $\mathrm{pH}$, total suspended sediment and chlorophyll-a on the Amazon floodplain. Limnology, 11: 155-166.

Best, R.C. 1982. Seasonal breeding in the Amazonian manatee, Trichechus inunguis (Mammalia: Sirenia). Biotropica, 14: 76-78.

Best, R.C. 1983. Apparent dry-season fasting in Amazonian manatees (Mammalia: Sirenia). Biotropica, 15: 61-64.

Brasil, 1967. Lei n ${ }^{\circ}$ 5.197, de 3 de janeiro de 1967. Dispóe sobre a proteção à fauna e dá outras providências (http://www.planalto. gov.br/ccivil_03/leis/L5197.htm). Accessed on 12/07/2016.

Calvimontes, J. 2009. Etnoconocimiento, uso y conservación del manatí Amazónico Trichechus inunguis en la Reserva de Desarrollo Sostenible
Amanã, Brasil. Dissertação de Mestrado, Universidad Nacional Agrária de La Molina, Peru. 210p.

Camara, G.; Souza, R.C.M.; Freitas, U.M.; Garrido, J. 1996. SPRING: Integrating remote sensing and GIS by object-oriented data modelling. Computers and Graphics, 20: 395-403.

Castello, L.; Macedo, M.N. 2015. Large-scale degradation of Amazonian freshwater ecosystems. Global Change Biology, 22: 990-1007.

Delaunay, B. 1934. Sur la sphère vide. A la mémoire de Georges Voronoï. Bulletin de l'Académie des Sciences de l'URSS, 6: 793-800.

Deutsch, C.; Reid, J.; Bonde, R.; Easton, D.E.; Kochman, H.I.; O'Shea, T.J. 2003. Seasonal movements, migratory behavior, and site fidelity of West Indian manatees along the Atlantic coast of the United States. Wildlife Monographs, 151: 1-77.

Domning, D.P. 1981. Distribution and status of manatees Trichechus spp. near the mouth of the Amazon River, Brazil. Biological Conservation, 19: 85-97.

Domning, D.P. 1982a. Evolution of Manatees: A Speculative History. Journal of Paleontology, 56: 599-619.

Domning, D.P. 1982b. Commercial exploitation of manatees Trichechus in Brazil c. 1785-1973. Biological Conservation, 22: 101-126.

Farner, D.S. 1986. Generation and regulation of annual cycles in migratory passerine birds. Integrative and Comparative Biology, 26: 493-501.

Fonseca, L.M.G. 1988. Restauração e interpolação de imagens do satélite Landsat por meio de técnicas de projeto de filtros FIR. Dissertação de Mestrado, Instituto Tecnológico de Aeronáutica, São José dos Campos, São Paulo. 148p.

Fyhn, M.; Molden, S.; Witter, M.P.; Moser, E.I.; Moser, M.B. 2004. Spatial representation in the entorhinal cortex. Science, 305: 1258-1264.

Gautestad, A.O.; Mysterud, A. 2013. The Lévy flight foraging hypothesis: forgetting about memory may lead to false verification of Brownian motion. Movement Ecology, 1: 9.

Griebel, U.; Schmid, A. 1996. Color Vision in the Manatee (Trichechus manatus). Vision Research, 36: 2747-2757.

Guterres-Pazin, M.; Marmontel, M.; Rosas, F.C.W.; Pazin, V.F.V.; Venticinque, E.M. 2014. Feeding Ecology of the Amazonian Manatee (Trichechus inunguis) in the Mamirauá and Amaná Sustainable Development Reserves, Brazil. Aquatic Mammals, 40: 139-149.

Jensen, J.R. 2006. Remote Sensing of the Environment: An Earth Resource Perspective, 2nd ed. Prentice Hall, New Jersey, 608p.

Junk, W.J.; Bayley, P.B.; Sparks, R.E. 1989. The Flood Pulse Concept in River-Floodplain Systems. Proceedings of the International Large River Symposium, Canadian Special Publication of Fisheries and Aquatic Sciences, p. 110-127 (www.dfo-mpo.gc.ca/ Library/111846.pdf). Accessed on 12/07/2016.

Junk, W.J. 2013. Current state of knowledge regarding South America wetlands and their future under global climate change. Aquatic Sciences, 75: 113-131. 
Kjelstrup, K.B.; Solstad, T.; Brun, V.H.; Hafting, T.; Leutgeb, S.; Witter, M.P.; Moser, E.I.; Moser, M.B. 2008. Finite Scale of Spatial Representation in the Hippocampus. Science, 321: $140-143$.

Lowrance. 2007. Lowrance Sonar Viewer 1.5. Lowrance Electronics. http://lowrance-sonar-viewer.software.informer.com/1.5/. Accessed on 12/07/2016.

Marmontel, M.; Guterres, M.G.; Meirelles, A.C.O.; Calvimontes, J.; Rosas, F.C.W. 2002. Lago Amanã: Destino estival de manaties amazónicos en la Amazônia Occidental brasileña. X Reunión de Trabajo de Especialistas en Mamiferos Acuáticos y IV Congreso de la Sociedad Latinoamericana de Especialistas em Mamíferos Acuáticos. Valdivia, Chile.

Mertes, L.A.K. 1994. Rates of flood-plain sedimentation on the central Amazon River. Geology, 22: 171-174.

Mertes, L.A.K.; Dunne, T.; Martinelli, L.A. 1996. Channelfloodplain geomorphology along the Solimões-Amazon River, Brazil. Geological Society of America Bulletin, 108: 1089-1107.

Polansky, L.; Kilian, W.; Wittemyer, G. 2015. Elucidating the significance of spatial memory on movement decisions by African savannah elephants using state-space models. Proceedings of the Royal Society B: Biological Sciences, 282: 20143042.

Powell, R.A.; Mitchell, M.S. 2012. What is a home range? Journal of Mammalogy, 93: 948-958.

Rosas, F.C.W. 1994. Biology, conservation and status of the Amazonian manatee Trichechus inunguis. Mammal Review, 24: 49-59.

Rossetti, D. de F.; Toledo, P.M.; de Goes, A.M. 2005. New geological framework for Western Amazonia (Brazil) and implications for biogeography and evolution. Quaternary Research, 63: 78-89.

Satizábal, P.; Mignucci-Giannoni, A.A; Duchêne, S.; CaicedoHerrera, D.; Perea-Sicchar, C.M.; García-Dávila, C.R.; Trujillo, F.; Caballero, S.J. 2012. Phylogeography and Sex-Biased
Dispersal across Riverine Manatee Populations (Trichechus inunguis and Trichechus manatus) in South America. PloS One, 7: e52468.

Sheppard, J.K.; Preen, A.R.; Marsh, H.; Lawler, I.R.; Whiting, S.D.; Jones, R.E. 2006. Movement heterogeneity of dugongs, Dugong dugon (Müller), over large spatial scales. Journal of Experimental Marine Biology and Ecology, 334: 64-83.

Silva, M.; Bermann, C.; Fearnside, P.M.; Millikan, B.; Baitelo, R; Rey, O.; Moreira, P.F.; Kishinami, R. 2012. O setor elétrico brasileiro e a sustentabilidade no século 21: Oportunidades e Desafios. Paula Franco Moreira (Org.), Brasília, 92p (https://www.internationalrivers.org/pt-br/resources/osetor-el\%C3\%A9trico-brasileiro-e-a-sustentabilidade-nos\%C3\%A9culo-21-\%E2\%80\%93-oportunidades-e-desafios). Accessed on 12/07/2016.

Thornback, J.; Jenkins, M. 1982. THE IUCN MAMMAL RED DATA BOOK Part 1: Threatened mammalian taxa of the Americas and the Australasian zoogeographic region (excluding Cetacea). The International Union for Conservation of Nature (IUCN) and United Nations Environment Program (UNEP), Gland, Switzerland. 516p.

West-Eberhard, M. 1989. Phenotypic plasticity and the origins of diversity. Annual Review of Ecology and Systematics, 20: 249-278.

Wirsing, A.J.; Heithaus, M.R.; Dill, L.M. 2007. Fear factor: do dugongs (Dugong dugon) trade food for safety from tiger sharks (Galeocerdo cuvier)? Oecologia, 153: 1031-1040.

Received: 30/03/2016

Accepted: 29/07/2016 
